\title{
Toleransi antarumat beragama dan relasinya terhadap pemeliharaan kebudayaan masyarakat Desa Pancasila, Sukoreno, Umbulsari, Jember
}

\author{
Tamarin Erningtyas, Ahmad Arif Widianto* \\ Universitas Negeri Malang, Jl. Semarang No. 5 Malang, Jawa Timur, Indonesia \\ *Penulis korespondensi, Surel: ahmad.arif.fis@um.ac.id
}

Paper received: 03-02-2021; revised: 15-02-2021; accepted: 28-02-2021

\begin{abstract}
Abstrak
Dalam sebuah masyarakat terutama masyarakat Indonesia, kita dihadapkan dengan konsekuensi adanya beberapa konflik yang melibatkan perselisihan ras, suku, bahkan agama. Seperti sebuah desa di Jember, Kecamatan Umbulsari, yang bernama desa Sukoreno. Untuk menghindari hal tersebut toleransi diagung-agungkan untuk disosialisasikan dan diinternalisasikan di setiap anggota masyarakat baik dari tingkat sekolah sampai pada aktivitas lainnya di Desa. Adanya sebuah perayaan besar dimanfaatkan oleh berbagai pihak sebagai ajang mempererat tali persaudaraan antar warga desa. Setiap adanya event, selalu ada tangan-tangan lain yang ikut membantu dikarenakan nilai luhur yang mengakar akan sebuah rasa gotong royong khas masyarakat desa, apapun agamnya, hal ini juga yang ingin dipertahankan oleh beberapa pihak untuk memelihara desa dengan pendapukkan desa Pancasila. Tulisan ini dibuat untuk mengetahui penyebab sebuah kebudayaan bisa diselenggarakan dalam keberagaman umat dan menjadikannya faktor pendorong toleransi. Penelitian ini dilakukan dengan cara wawancara dan merangkum beberapa informasi dari informan yang layak dijadiakn bahasan sesuai tema, secara purposive. Karena dengan adanya pendidikan pembiasaan local wisdom akan tetap terjaga. Bangsa Indonesia berkomiten bahwasannya negara multikultur dan multi agama ini perlu adanya komitmen yang kuat akan toleransi dan integrasi dalam pengemasannya. Kebiasaan, apresiasi, dan partisipasi masyaraat inilah yang nantinya akan membentuk kerukunan sesuai kebiasaan uri-uri budaya yang dilakukanya guna mempersatukan perbedaan akan kesadaran kognitif yang terintegrasi.
\end{abstract}

Kata kunci: toleransi; Desa Pancasila

\section{Pendahuluan}

Pluralitas dan heterogenitas masyarakat Indonesia tercermin dalam semboyan negara, yakni "Bhineka Tunggal Ika” serta identitas negara yang terdapat dalam 5 sila di Pancasila. Sila pertama yaitu "Ketuhanan Yang Maha Esa", sebagai pondasi dari segala sila, menjadikan warga Indonesia bebas memeluk agama dengan syarat mengakui agama di Indonesai dan menghormatinya. Karena keberagaman wilayah serta culturenya, agama di Indonesia menjadi beragam dan yang diakui pemerintaha Republik Indonesia secara administratif adalah Islam, Kristen Protestan, Katolik, Hindu, Budha, dan Kongguchu (Saifudin 2000: 2). Kesatuan dalam keragaman budaya bangsa memiliki keunikan dalam menjaga kerukunan antarumat beragama yang harus diakomodasi oleh seluruh warga negara, secara sadar berdasarkan falsafah negara yang telah disepakati bersama yaitu Pancasila. Agama selalu terintegrasi dengan sebuah budaya, dikarenakan agama sebagai sumber kebudayaan tertinggi dalam kehidupan manusia, mengandung sebuah proses (sublime) aspirasi manusia terdalam, dan dijadikan candu oleh manusia itu, menurut Karl Marx (O’Dea 1966: 2).

Indonesia sebagai negara multicultural dan nation-state dapat dijadikan sebagai barometer negara multi-culture di dunia. Namun, kemajemukan sebuah agama terkadang 
membawa potensi persoalan serta konflik antar masyarakat sendiri yang berorientasi terhadap perpecahan bangsa. Munculnya benih konflik pada masyarakat multikultur dapat mengakibatkan pemisahan yang menimbulkan sifat ke-kita-an yang bukan bagian dari bangsa Indonesia (Lestari, 2015). Sehingga terlepas dari konsep keharmonisan Pancasila, di lain sisi juga terdapat sebuah lack di dalamnya, berupa ancaman pemecah bangsa yang didasari sikap kesadaran akan toleransi masyarakat terkait kebudayan dan keberagaman itu sendiri. Dari permasalahan tersebut masyarakat yang memiliki keberagaman budaya dan agama akan lebih rentan terhadap konflik sosial yang pecah akibat sebuah intolerance sebuah kelompok tertentu.

Hal ini bisa ditemui dan digali di sebuah desa yang baru- baru ini dijuluki sebagai desa Pancasila, yaitu Desa Sukorenao, Umbulsari, Jember. Uri-uri budaya di Desa Sukoreno, Umbulsari, Jember yang mungkin memasukkan pengetahuan lokal, keterampilan lokal, kecerdasan lokal, sumberdaya lokal, proses sosial lokal, norma-etika lokal, dan adat istiadat lokal mengakibatkan sebuah Tolerance Intelegent yang tumbuh mengakar. Untuk itu sebuah negara ataupun wilayah lainnya di Indonesia hendaknya menumbuhkan sikap seperti di Desa pancasila Sukoreno, Kecamatan Umbulsari, Kabupaten Jember, Jawa Timur, di mana kemungkinan adanya sebuh lack ataupun konflik sangat kecil, karena keberagaman agama dan relasinya terhadapat budaya membentuk sebuah konsensus bersama. Emile Durkheim menuturkan sebuah eksistensi di dalam masyarkat ada karena sebuah konsensus moral (Purboningsih, 2015). Sibarani (Khusniati,2014:69) menyimpulkan bahwa kearifan lokal adalah pengetahuan asli (indigineous knowledge) atau kecerdasan lokal (local genius) suatu masyarakat yang berasal dari nilai luhur tradisi budaya untuk mengatur tatanan kehidupan masyarakat dalam rangka mencapai kemajuan komunitas baik dalam penciptaan kedamaian maupun peningkatan kesejahteraaan masyarakat.

Keberagaman agama di Jember Menurut data (BPS Provinsi Jawa Timur) tahun 2016, tercatat jember memiliki 2.294.519 jiwa beragama Islam, 28.926 jiwa beragama protestan, 19.288 jiwa beragama Katolik, 1.609 jiwa beragama Hindu, 3.401 jiwa beragama Budha, 343 jiwa kepercayaan lainnya. Desa Sukoreno yang telah didapuk menjadi desa Pancasila di Kabupaten Jember ini dapat memeberikan gambaran dalam kerukunan umat beragama dengan turut andil serta guyub rukun untuk mengadakan upacara-upacara keagamaan ataupun perayaan hari raya dari masing-masing agama yang ada, yakni Islam, Hindu, Katolik, dan Protestan.

Sebuah toleransi yang muncul akibat adanya konsensus, dijadikan sebuah realisasi dari pengekspresian kelompok akan pengalaman dan kedalaman sebuah agama yang dianutnya (Joachim, 1958). Sebuah pengalaman dan pengakuan yang diwujudkan dalam realita adalah sebuah nilai yang memang ada diajarkan setiap agama dalam menjalin hubungan sosial antar umatnya atau umat agama lain sebagai wujud keberagaman manusia yang ada dan sesuatu yang vital dalam menjalin setiap hubungan sosialnya yang membudaya. Interaksi sosial terjadi akibat adanya hubungan timbal balik antara individu dengan individu, individu dengan kelompok, kelompok dengan kelompok yang memiliki tujuan yang sama (Sujarwanto, 2012). Tak jarang di dalam sebuah komunitas masyarakat yang mempunyai kemajemukan dalam beragama dapat memunculkan kebudayaan bersama yang dapat mengintegrasi.

Permasalahannya kemudian adalah bagaimana sebuah masyarakat di Sukoreno dengan perbedaan agamanya, mampu menjadikan kebudayaan setiap agama warganya menjadi 
kebudayaan bersama yang dilaksanakan secara beriringan tanpa meninggalkan nilai dan norma agama masing-masing? Dalam perspektif yang bersebrangan, bagaimana nilai-nilai dari agama masyarakat yang ada di Sukoreno mampu menciptakan sebuah toleransi beragama yang saling terintegrasi dalam satu lingkup kebudayaan bersama? Pertanyaan ini akan mengorek realitas sebuah pengakomodasian manusia di dalam keberagaman dan perbedaan kehidupan sosial (Casram, 2016). Penulis berargumen bahwa toleransi yang ada di desa Sukoreno di dasarkan oleh kebudayaan yang dianut dari awal sebuah hubungan masyarakat desa terbentuk dengan ciri khas mekaniknya, serta nilai luhur kebaikan agama, tanpa memandang berbedaan agama sekalipun. Dan kontribusi dalam pengintegrasian sebuah ideologi, yaitu Pancasila oleh pihak-pihak yang mengerti dan terkait mampu menumbuhkan kesadaran toleransi yang lebih. Karena sebuah ilmu menemukan hakekat dan konsep keanekaragamn dalam beragama itu sendiri sebagai manusia yang ihwal (Marzali, 2016).

Dari latar belakang yang sudah dipaparkan sebelumnya, tulisan ini akan menjelaskan bagaimana berbedaan agama beserta nilai-nilai dan norma yang diyakininya mampu dijadikan sebagai alat untuk memepengaruhi, menginternalisasikan, dan mengatur sedemiakian rupa agar diterapkan oleh masyarakat sekitar desa Sukoreno sebagai kebudayaan bersama. Namun, hal ini lantas berhubungan dengan nilai dan adat luhur yang ada di sebuah desa, jika dibandingkan dengan kota. Sebuah desa sendiri mempunyai karakteristik yang berlandaskan kegotong-royongan di mana hal ini kan mengakar di sebuah pedesaan yang memang dalam kesehariannya intensitas dalam berinteraksi, bertukar ide, dan bahkan norma-norma mengikat yang saling disepakati akan terinternalisasi secara kuat. Tulisan ini lebih mengeksplorasi akan peranan kebudayaan luhur beserta peranan internalisasi nilai yang menjadikan masyarakat menjujung tinggi kebudayaan di atas keberagaman dengan menggunakan teori verstehen.

Meskipun tidak semua masyarakatnya menerapkan toleransinya yang tinggi antar satu agama ke agama lain, dalam sebuah keseharian dan acara khusus, mereka akan terdesak oleh mayoritas pelaku budaya sebagai Majority Rule. Memahami makna terdalam dari sebuah nilai sebuah kebudayaan yang disepakati bersama dalam membawa ketoleransian di atas keberagaman agama. Agama sebagai sistem simbol, psikological fungsional, budaya, sosial, hingga moods dan motivasi yang seolah dinampakan secara realistik (Geertz 1966: 4). Hal ini lah yang menjadi pembeda dengan penelitian-penelitian terdahulu yang sering memfokuskan tentang latarbelakang sebuah toleransi dan modelnya dalam keberagman (Huda, 2015).

\section{Metode}

Penelitian ini menggunakan metode kualitatif dengan pendekatan verstehen. Metode kualitatif dipilih karena dapat menjelasakn sebuah makna toleransi di Desa Sukorena secara mendalam dan holistik dan penjelasan sebab-akibat dari tindakan aktor akan relasinya dengan sebuah kebudayaan itu.

Data yang dikumpulkan dalam penelitian diantaranya data sekunder dan data primer. Data sekunder diperoleh dari data yang sudah ada dari berbagai sumber referensi, sedangkan data primer diperoleh dengan melalui proses wawancara (interview) yang dilakukan secara terstruktur kepada informan-informan yang terpilih di objek lokasi penelitian. Subjek penelitian dipilih dengan cara purposive, yaitu informan-informan tersebut diambil dari sebagaian besar tokoh masyarakat dalam ranah budaya dan keagamaan, pemerintah desa, serta masyarakat sekitar yang menguasai. Dengan cara merinci kekhususan temuan tersebut 
kedalam kategori-kategori yang digeneralisasikan (Purposive Sampling) (Sugiyono, 2013: 218).

\section{Hasil dan Pembahasan}

\subsection{Agama dan Budaya}

Asal usul nama desa Sukoreno karena di desa ini terdiri dari 4 agama yang berbeda dan hidup berdampingan tanpa menimbulkan konflik di lingkungan masyarakat sejak jaman dulu. Agama yang dianut warganya terdiri dari Islam, Hindu, Katholik, Protestan, ditambah kepercayaan Sapda Dharma dan Ilmu Sejati. Setiap agama tersebut mrmpunyai sebuah perayaan dalam mengiringi ibadah mereka masing-masing. Di dalam perayaan tersebut akan memuat nilai-nilai kebudayaan yang memang sudah ada sejak dulu, kebudayaan jawa sebelum agama lainlah yang mereka junjung tinggi sampai sekarang, seperti Genderen. Agama adalah pemandu kehidupan manusia dan merupakan kebudayaan paling tinggi, sublime, dan candu sebagai pegangan hidup (O’Dea 1966: 2).

Kebudayaan baik yang termuat dalam sebuah agama akan tetap dijalankan oleh penganutnya sebagai identitas diri, dan juga sebuah status yang bisa didapatkan dan dipertahankan untuk menjaga sebuah eksistensi dan jati diri. Oleh karena itu masyarakat atau sekelompok tanpa kebudayaan, mereka hidup tanpa status yang jelas di dalam masyarakat (Suwardi, 2015). Warga desa Sukoreno melakukan sebuah cross kebudayaan saat melakukan upacara besar dikarenakan oleh adanya kesadaran akan umat yang hidup berdampingan, makhluk sosial, dan rasa bersaudara karena dalam ruang lingkup setiap hari bertemu dan berhubungan yang membentuk toleransi sebagai makanan keseharian. Toleransi yang terbentuk karena hubungan kebudayaan masyarkat lokal dengan dinding perbedaan keyakinan bisa saja mejadi longgar, karenadanya agma sebagai kelembutan hati dan perilaku, serta kesabaran dan keringanan dalam menjalin hubungan antara manusia sebagai makhluk Tuhan (Hornby, 1995).

\subsection{Wujud Toleransi Antar Agama Yang Membudaya}

Sukoreno adalah sebuah desa di Jember yang mendapatkan dapukan sebagai desa Pancasila secara politis dimuali pada tahun awal 2018 semenjak pernyataan dari Bupati Jember, Faida. Dapukan Desa Sukoreno sebagai Desa Pancasila. Dilatarbelakangi oleh keberagaman agama dan beberapa perayaan agama besar dan yang paling disosroti adalah pawai ogoh-ogohnya dalam menjelang hari raya nyepi (jemberkab, 2018). Agama adalah candu, itulah yang dikatakan Karl Marx. Agama adalah sebuah belief atau kepercayaan dan ritual dalam upacara yang dianut oleh sebuah kelompok masyarakat. Di dalam desa ini sebuah perayaan budaya agama, contohnya adalah pawainya ogoh-ogoh memang dapat dinikmati oleh banyak orang karena memang sebagian upacaranya dilakuan diluar sepanjang perjalanan dan melewat pemukiman-pemukiman, lantas menarik bahkan mengundang khalayak untuk melihatnya bahkan berpartisipasi karena sudah akrab dan setiap hari srawung dengan warga lain, di luar aspek ibadah agamanya. Tak heran ogoh-ogoh menjadi wujud toleransi yang menonjol karena bisa dilihat langsung. Mereka yang mempunyai status lantas dengan sebuah dorongan diri akan prestise akan melakukan pretensi murni dari sebuah budaya agama tertentu yang murni pembawaan, lalu dilakukan sebuah pretensi untuk membentuk kebudayaan baru lagi (Budi, 2009). 
Beda lagi dengan perayaan agama Kristen Khatolik di desa itu, yaitu paskah. Perayaan paskah tertutup hanya keluarga dan sesama umat yang nantinya ibadah di gereja, bentuk budaya umat katolik ini tidak bisa diikuti dan menjadi kebudayaan bersama warga Desa, karena bersifak inklusif. Sebuah ibadah dengan doa penganutnya meskipun dirayankan bersama tidak bisa ikut berdoa, karena doa sifatnya sangat psiritual. Vilfredo Pareto seorang sosiolog Itali , mendefinisikan agama sebagai sesuatu yang ada di luar, tak terjamah (an intangible beyond) dan berkaitan dengan pengalaman dengan yang ada di atas (transcends experience). Meskupin bukan berarti umat Katholik di desa Sukoreno tidak berpartisipasi dengan acara event besar perayaan agama lainnya. Karena sebuah agama tak lepas dari perilaku interaksi dan merupakan bagian dari culture, agama sendiri tidak akan bertahan tanpa sebuah kebudayaan yang dilakukan dalam pemeliharaan tertentu. Kebudayaan akan terus mempertahankan nilai dan pengenalan ciri khas sebuah agama. Sebuah kebudayaan tanpa agama tidaklah bertahan lama kaena tidak adanya sebuah nilai yang dispriritualkan, begitupun sebuah agama tak akan tersebar dengan baik tanpa adanya kebudayaan dri agama tersebut yang mengiringinya (Tedi, 2007).

Selain itu, peran tokoh atau pamong dalam menyebarkan pandangan atau bahkan keterlibatan dalam sebuah tradisi juga dipengaruhi oleh nilai yang ada dalam kitab agama masing-masing, sehingga agama juga dapat digunakan sebagai alat pengendali perilaku sebuah kelompok (Sugiharto, 2005: 50). Di mana perilaku yang didasari oleh ketaatan beragama pada sebuah kelompok ataupun individu mampu dijadikan acuan melakukan perilaku sesuai peranan (role) yang merupakan bagian dari kedudukan yang bersifat dinamis, dengan cara melakukan kewajiban dan haknya dalam peran yang didapatkan (Soerjono, 2006).

\subsection{Latar Belakang Budaya dan Nilai}

Jumlah penduduk Kabupaten Jember tahun 2017, berjumlah 2.430.185 jiwa. Dengan jumlah laki-laki 1.194.496 jiwa, perempuan 1.235.689 jiwa. Kecamatan di jember dibagi atas 31 kecamatan, salah satunya adalah Kecamatan Umbulsari berjumlah 72.444 jiwa dengan jumlah laki-laki 35.826, perempuan 36.618 ( BPS Kabupaten Jember, 2018). Masyarakat Sukoreno beranggapan bahwa agama dapat mendatangkan kemakmuran antar masyarakat, hal tersebut terbukti setiap pelaksanaan acara besar keagamaan Desa Sukoreno menjadi sorotan publik dan masyarakat mancanegaran maupun lokal dalam kaitannya destinasi wisata religi yang tentunya dapat menjadi pengaruh baik bagi masyarakat sekitar dan tentunya mendongkrak perekonomian masyarakat. Kesadara akan adanya kebudayaan dan perayaan besar bersama, dapat djadikan peluang sebagai perantara menumbuhkan cipta, karsa, dan karya dalam mempertahankan sebuha eksistensi, maka kan dilakukan secara turun-menurun untuk melangsungkan kehidupan yang harmonis bagi kelompok (Sumarsono dkk 2007).

Acara besar agama desa Sukoreno selaluu disambut antusias wisatawan religi dari seluruh masyarakat, acara agama dijadikan sebagai ajang perekatan antar umat beragama yang ditunjukan dengan adanya masing-masing pemuka agama yang ada ikut serta dalam perayaan agama lain sebagai sikap saling menghormati dan montolelir masyarakat agar terhindar dari kontrkasi sosial yang tentunya menimbulkan perpecahan. Unesco mengartikan sebuah toleransi adalah sikap saling hormat, menerima, dan menghargai di tengah keberagaman budaya. Dalam pengekspresian karakter manusia kan kebebasan (Walzer, 1997). 


\subsection{Pendidikan Lintas Agama Desa Sukoreno Sebagai Wujud Eksternalisasi dan Internalisasi Budaya}

Indonesia yang berasal dari masyarakat beraneka ragam sehingga dilahirkan semboyan Bhineka Tunggal Ika merupakan kearifan lokal yang sangat melipah. Hal inilah dijunjung dan diterapkan dalam proses pengajaran pendidikan Formal di Sekolah Dasar Katolik. ST. Yusuf Sukoreno Jalan Argopuro No 109 Kec. Umbulsari, Jember. Kearifan lokal perlu dilestarikan oleh generasi muda sebagai bentuk tanggung jawab atas warisan nenek moyang, kearifan ataupun adat bisa diturunkan lewat pendidikan yang terintegrasi. Oleh karena itu alangkah baiknya sebuah kearifan lokal tetap ditampilkan dan digunakan guna pemberian makna aktivitas yang tak lupa akan aktivitas lokal daerah terutama di pedesaan dalam mengembangkan sebuah toleransi dan rasa gotong royong yang kuat.

Seperti faktor pendidikan di desa Sukoreno sebagai jembatan kearifan lokal itu sendiri, dengan adanya SD katolik yang terintegrasi dengan pendidikan, lalu menyediakan akses bagi anak lintas agama mengenyam pendidikan membuat proses pembelajaran akan sebuah nilai toleransi semakin kuat. SD katolik ini merupakan SD tertua dan ada kaitannya dengan Mbah Ronggo Prakasa pendirinya sendiri pada tahun tahun 1920-an. Mereka mau menerima peserta didik dari agama manapun, baik hindu, islam, kristen, katolik, sapta dharma. Sistem pembagian ajaran agama dalam sebuah aula akan bergilir, pembagian ini berlaku khusus hari jumat untuk materi agama agar tetap terfokus dan mendapat pendidikan keagamaan sesuai porsinya. Di sini para warga sekolahnya tak pernah menanyakan agama yang dianut oleh individu tertentu, mereka sudah sadar akan keberagaman itu sendiri. Selain budaya, pendidikan juga mempengaruhi terjadinya kontruksi toleransi yang kuat, utuh, dan menyeluruh, karena dengan adanya pendidikan pembiasaan local wisdom akan tetap terjaga. Bangsa Indonesia berkomiten bahwasannya negara multikultur dan multi agama ini perlu adanya komitmen yang kuat akan toleransi dan integrasi dalam pengemasannya. (Sudarma, 2007).

Inti menanamkan toleransi itu sendiri dimulai dari anak- anak lewat pendidikan yang ada. Kepala sekolah latar belakang pergaulannya sendiri berteman dengan teman yg $\mathrm{Nu}$, Muhammadiyah, dll dalam sebuah komunitas keagamaan. Karena hakikatnya agama itu urusan masing-masing individu dengan Tuhan. Semua wakil agama yang telah diobservasi, survey, dan wawancarai speak up dan selalu membahas dalam pengulangannya tentang kebiasaan budaya Rewang dan Slametan yang selalu dilakukan untuk setiap acara warga. Karena sebenarnya konfrontasi budaya dua arah di mana budaya yang satu dengan budaya yang lainnya saling pengaruh mempengaruhi akan menghasilkan budaya yang lebih kaya (kompilasi) (Achmad, 2004, h. 14-15).

Gotong royong yang ditonjolkan di dalam ruang umat katolik ini dapat ditemui. Seperti contoh kecil adanya bantuan dari teman-teman komunitas agama lain membantu mengamankan peribadatan yang dilakukan umat katolik saat paskah tanpa di minta. Saling terbuka, semangat gotong royong, dan kebiasaan yang diperoleh dari budaya yang dipelajari di sekolah dan penerapan keseharian di lingungan yang majemuk dijunjung tinggi melebihi apapaun di desa ini. Gotong-royong ini sendiri merupakan budaya lokal yang dikuatkan oleh kearifan lokal itu sendiri oleh karena itu masyarakatnya sangat menjujung erat dan masih terpelihara sedemian rupa. Seperti yang dikemukanan Wajidi (2014) dalam sebuah interaksi (dialektika) antar agama dan budaya sebagai pengikatnya akan ada hubungan saling mempengaruhi karena adanya nilai dan simbol dalam upacara yang diadakan dalam 
momentum tertentu yang tak selalu ada di hari lainnya, munculah rasa empati dan simpati untuk menyamaratakan hak maupun kewajiban.

Membicarakan mengenai agama katolik maupun agama lain di Sukorena, tak jarang masyarakat Out Group mungkin akan menganggap di desa ini sebenarnya memiliki dua wajah yang berlainan. Jadi sebuah walaupun desa sukoreno ini terkenal akan berbagai simbol akan toleransi beragama dengan mengungsung kekayaan budaya dan anutan kearifan lokal yang kuat, sebuah agama itu sendiri pasti memiliki kekuatan untuk merangkul sesama, menciptakan persatuan, kedamaian, kebaikina. Namun, disisi lain agama merukapan hal sensitif yang rentan akan konflik dan perpecahan karena salah presepsi maupun pandangan yang berlainan layaknya pedang bermata dua. (Muhammad, 1997).

Budaya Rewang dan Salmetan menjadi pemersatu warga beda agama karena dengan slametan sebuah acar doa-doa diperkenankan untuk berdoa sesuai keyaknan masing-masing dan makanan yang ada sudah pasti semua warga bisa memakannya dan halal karena daya pikir dan pengkoordinasiaan warga sebagai kebijakkan lokal warga sukoreno tentang perbedaan yang ada. Local jenius dalam hal mencapai kesjahteraan yang ada. Inilah yang dinamakan Local Wisdom to Religious Tolerance. Menurut Purna, Made (2016) dalam penelitiannya mengenai keberagaman suku tengger toleransi ada dikarenakan dogma agama yang menjadi kekuatan kekuatan kearifan lokal dalam hal pembelajaran dan integrasi tidak dari tokoh, warga, dan pemerintah tetapi juga keterkaitan antar ketiganya dalam menumbuhkan uri-uri budanya mengadakan, melestarikan, mempertahankan tradisi, dan adanya kesepakatan bersama mengenai kebudayaan yang akan dijunjung agar tak ada yang mendominasi kaum minoritas.

\subsection{Peranan Stake Holder dalam Menjaga Keharmonisan Desa Pancasila}

Di dalam kehidupan desa Sukoreno ini setelah berbagai pemaparan, kondisi lapangan, dan sitem pengkoordinasian masyarakatnya. Secara tidak langsung masyarakat di desa Ini memberlakukan Trilogy Kerukunan beragama. Yaitu kerukunan yang harus dijaga di dalam kelompok agama yang sama (intern), kerukunan yang dijaga antara umat beragama (ektren), yang terakhir yaitu menjaga kerukunan umat beragam dengan pemerintah (Depag RI, 1989).

Kearifan lokal sendiri dapat berupa simbol, sistem keorganisasian, pandangan, semboyan, dan budaya asli masyarakat yang dibiasakan atau diciptaan oleh sebuah sitem komunal masyarakat dalam menuju kesejahteraan, kedamaian, dan harmoni sosial sebagai tujuan utama kearifan tersebut (Joko, Tri. 2014). Meskipun dalam membuat sebuah kearifan lokal ini dapat dipegang terus oleh para nenerus anak cucu maka perlu diadakan berulangulang dengan waktu yang tak sebentar untuk menjadi kearfan local yang utuh dan terintegrasi dalam kehidupan masyarakat yang harmonis. Tentunya kearifan lokal tersebut berbeda antar satu masyarakat dengan masyrakat lainnya karena latar belakang munculnya sebuah kebijaksaan lokal yang ada dilatarbelakangi oleh faktor yang berbeda. Kearifan lokal inilah menjadi pendorong, pemersatu, dan pedoman bagi masyarakat desa Sukoreno ditandai dengan pengkoordninasian antar umat beragama mengenai sebuah kebudayaan satu agama yang dianggap bersama menjadi simbol desa, lalu sebuah simbol bunga suko yang beragama yag secara tidak langsung menjadikan simbol bahwa desa mereka awalnya memang berwarna warna seperti satu pohon yang memiliki banyak warna, dari situlah akan muncul kesadaran kolektif yang memang dicakup oleh persamaan akan simbol yang lantas setiap masyarakat bertanggung jawab menjaga simbol asal usul dan budaya yang dapat menjadi pestarian budaya 
mereka sendiri agar tidak pernah mati. Kebiasaan, apresiasi, dan partisipasi masyaraat inilah yang nantinya akan membentuk kerukunan sesuai kebiasaan uri-uri budaya yang dlakuknaaaya guna mempersatukan perbedaan akan kesadaran kognitif yang terintegrasi (Haba, 2007).

Seperti apa yang Talcott Parsons katakan (1958: 208-209), agama mempunyai fungsi praktif dalam menjalankan aktifitas sesuai dengan pedoman masing-masing kitab, hal itu akan mempengaruhi dalam kehidupan sosial kesehariannya, yang menjadi jawaban tentang hakikat hidup para pemeluknya.

\section{Simpulan}

Desa Sukoreno merupakan salah satu desa multikulture dengan keberagaman agama yang berada dalam satu wilayah dan memiliki ciri khas tersendiri dalam melakukan ritual keagamaan. Permasalahan serta ketidaksamaan dalam hal beragama di Desa Sukoreno lantas tiadk menjadikan semua komponennya berpencar. Salah satu desa Pancasila Di Jawa Timur ini menjadikan sebuah diferensiasi tersebut sebagai citra dalam memperbaiki hubungan serta implementasi terhadap sikap ketakwaan agama yang lebih toleransi dilandaskan interaksi, komunikasi terus-menerus, pendidikan, dan sistem pemerintahan yang saling mengakomodasi. Ketika sebuah kebiasaan, apresiasi, dan partisipasi masyaraat membentuk kerukunan sesuai kebiasaan uri-uri budaya yang dilakukanya sejak lama, secara terstruktu dan menumpuk akan mempersatukan perbedaan berdasarkan kesadaran kognitif yang terintegrasi.

Agama yang mempunyai fungsi pengontrol, budaya yang mempunyai fungsi sebagai pemersatu, masyarakat yang mempunyai fungsi pemelihara, dan tetua adat dalam artian pemerintah yang mau memberikan sarana dan prasarana agar hal tersebut tetep terjalin. Menjadikan alur dan mengikatkan semua aspek dalam menjalin kehidupan sosial secara terusmenerus sebagai manusia guna mengjalankan sifat aslinya sebagai makhluk sosial, mau tidak mau apa yang dia kerjakan, pola pikir, dan tujuan akan selalu berfokus pada tujuan bersama untuk mencapai keharmonisan dan kebaikaan. Hal ini selalu berhubungan karena dasar sebuah agama adalah nilai ilmu yang dimiliki individu atau sekelompok orang dalam membentuk tatanan baru dalam cangkang budayanya.

\section{Daftar Rujukan}

Adiansyah, Ryko. (2017). Persimpangan Antara Agama dan Budaya (Proses Akulturasi Islam dengan Slametan dalam Budaya Jawa). Intelektualita, 06 (02): 295-310.

Departemen Agama RI. (1989). Pedoman Dasar Kerukunan Umat Beragama. Jakarta: Sekretariat Jenderal Departemen Agama Republik Indonesia

Geertz, C. (1966), O'Dea (1969), Lessa (1978). dalam Marzali, Amri. (2016). Agama dan Kebudayaan. Indonesian Journal of Anthropology: 1(1), 56-75.

Haba, John. (2007). Revitalisasi Kearifan Lokal: Studi Resolusi Konflik di Kalimantan Barat, Maluku, dan Poso. Jakarta: ICIP dan Eropean Commision.

Haryanto, Joko Tri. (2014). Kearifan lokal pendukung kerukunan beragama pada komunitas Tengger Malang Jatim. Jurnal "Analisa", 21 (02) : 201-213.

Hariyono. (2014). Ideologi Pancasila Roh Progresif Nasionalisme Indonesia. Malang: Intans Publishing.

Huda, Sholihul. (2015). Kampung Inklusif. Jurnal Studi Agama-Agama: 1(1).

Jemberkab.go.od. Tanggal Akses 3, Mei 2020, 100.22 wib.

Joachim Wach, The Comparative Study of Religion (New York: Colombia University Press, 1958), 121- 132. 
Khusniati, Miranita. (2014). Model Pembelajaran Sains Berbasis Kearifan Lokal Dalam Menumbuhkan Karakter Konservasi. Indonesian Journal of Conservation, 3: (1)

Michael Walzer (1997) dan Hornby(1995). dalam Casram. (2016). Membangun Sikap Toleransi Beragama Dalam Masyarakat Plural. Jurnal Ilmia Agama Dan Sosial Budaya: 1(2) , 187-198.

Mubarak, Achmad. (2004). Nasionalis Religius Jati Diri Bangsa Indonesia. Jatiwaringin: PT.Bina Rena Pariwara.

Muhammad, Afif. (1997). Kerukunan Beragama Pada Era Globalisasi, Makalah Orasi Ilmiah pada Dies Natalis IAIN Sunan Gunung Jati Bandung ke-29, tanggal 8 April 1997

Saifudin, Achmad Fedyani. (2000). Agama Dalam Politik Keseragaman. Jakarta: Badan Penelitian dan Pengembangan Agama, Departemen Agama RI.

Sudarma, I. W. (2007). Kajian Antaretnik dalam Pelaksanaan Upacara Tradisional di Pura Subak Medewi Jembrana. Jurnal Penelitian Sejarah dan Nilai Tradisional, I(1) 122-125.

Sugiharto, Bambang. (2005). "Ilmu dan Agama dalam Kurikulum Perguruan Tinggi”, dalam Zainal.

Sujarwanto, I. (2012). Interaksi sosial antar umat beragama (studi kasus pada masyarakat Karangmalang Kedungbanteng Kabupaten Tegal).

Sumarsono, dkk. (2007). Pendidikan Kewarganegaraan. Jakarta: PT Gramedia Pustaka Utama.

Suwardi Endraswara, Etnologi Jawa, (Yogyakarta: CAPS, 2015). 1563 Budi Munawwar \& Rachman,

Parsons, Talcott, and Krober A. L. (1958). The Concepts of Culture and Social System In The American. New York: Free Press, hlmn 208-209.

Purboningsih, SD. (2015). Teori konflik dan konsensus. Digilib.uinsby.ac.id.

Purna, I Made. (2016). Kearifan lokal masyarakat Desa Mbawa dalam mewujudkan toleransi beragama. Jurnal Pendidikan dan Kebudayaan, 1(2: 261-277)

Tedi Sutardi, Antropologi. Mengungkap keragaman budaya, (Bandung: PT. Setia Purna Inves, 2007) h. 22

Wajidi. (2014). Hubungan Islam dan Budaya dalam Tradisi Ba-Ayun Maulid di Masjid Banua Halat Kabupaten Tapin, Kalimantan Selatan. Jurnal Penelitian Sejarah dan Budaya Patanjala, 6(3) 350-354. 